\title{
'Antisemitism is just part of my day-to-day life': Coping mechanisms adopted by Orthodox Jews in North London
}

International Review of Victimology $1-16$

(C) The Author(s) 2021

\section{(c) (i) \$}

Article reuse guidelines: sagepub.com/journals-permissions DOI: 10.1 I77/026975802 I 1006663 journals.sagepub.com/home/irv @SAGE

\section{Maya Flax}

University of West London, UK

\begin{abstract}
This paper analyses the coping mechanisms which Orthodox Jews in North London have adopted in managing antisemitism. The study, which was informed by a sociological framework, employed a qualitative approach using 28 semi-structured interviews and five focus groups. The findings reveal that despite the high frequency of the victimisation, and despite the awareness among respondents that antisemitism has seen a resurgence in recent years, Orthodox Jews have managed to accept the victimisation. The way the Orthodox Jewish community has managed their victimisation of antisemitism is argued to be profoundly different from the dominant narratives of hate crime victims, in that by and large the majority of respondents accepted their victimisation. It proposes that respondents were able to show agency and to normalise the victimisation because of their strong religious identity and close community ties.
\end{abstract}

\section{Keywords}

Normalisation, acceptance, victimisation, religious identity, community ties

According to the Crime Survey for England and Wales (CSEW), hate crime has been on the rise (Home Office, 2020) and antisemitism is no exception. The resurgence of antisemitism within the UK is documented among police and communal records (Community Security Trust, 2017; Corcoran and Smith, 2016). These records show the prevalence of antisemitic victimisation among the Orthodox Jewish community and yet the everyday experiences of the Orthodox Jewish community appear marginalised in academic literature. Whilst there is a vast amount of research on

\section{Corresponding author:}

Maya Flax, University of West London, School of Law and Criminology, St Mary's Road, Ealing, London W5 5RF, UK. Email: Maya.Flax@uwl.ac.uk 
International Review of Victimology

antisemitism, there is very little empirical research specifically on the antisemitic victimisation of Orthodox Jews. This article aims to include voices of Orthodox Jewish individuals in the developing literature, in particular, the coping mechanisms which they adopt in order to manage the victimisation. It is important to understand their coping mechanisms because levels of antisemitism are on the rise.

Records of antisemitic incidents in the UK have reached an all-time high in the last 3-5 years. The Community Security Trust (CST), a charitable organisation that represents and advises the Jewish community on matters of antisemitism, security and terrorism, has recorded the highest level of reported antisemitic crimes since statistics were first assembled. CST Chief Executive David Delew said, 'Anti-Semitism is having an increasing impact on British Jews and hatred and anger that lies behind it is spreading' (Morgan, 2017). The previous UK Chief Rabbi, Sir Jonathan Sacks, warned of a 'tsunami of antisemitism' sweeping the world (Hastings, 2005). Kushner (2013), in referring to Sacks' comments, states that 'There is a much greater implication that antisemitism can erupt, very quickly, at any time, and, like a virus out of control, wreak devastation'. The Chief Rabbi, Rabbi Efraim Mirwis, in oral evidence given on 14 July 2016 to the Home Affairs Committee, in preparation of the 2016-2017 report on antisemitism (Corcoran and Smith, 2016), echoed that, overall, British Jews are happy to be living in the UK. But that within this context, the problem of antisemitism, which used to be smaller, is now getting bigger: 'And it could get bigger and bigger, unless we deal with it effectively'.

The European Union Agency for Fundamental Rights (FRA, 2013) compared the perceptions of British Jews with the perceptions of Jews among seven other EU Member States. The survey demonstrated that in 2013 Britain was considered more of an accepting and tolerant environment for Jews than certain other parts of Europe. However, the CST statistics reveal that it is the Orthodox Jewish community which faces the highest rate of physical assaults among British Jewry (CST, 2017). It is their high visibility and highly distinctive dress which makes them particularly vulnerable to attack and hence more likely targets than secular Jews. Unlike secular Jews who are not easily identifiable as a distinctive group and are more integrated into secular culture, the Orthodox Jewish community are prime targets of antisemitic victimisation and are most vulnerable to attack.

The impacts of hate crime are well documented (Iganski and Lagou, 2014). Hate crime has been described as a form of terrorism, as these offences incite inner turmoil and terror with the victims (Herek et al., 2002). The potential scale of harm of hate crime offences is greater than the same crimes without the bias element (Dzelme, 2008). Studies show that victims of bias crimes portrayed considerably higher levels of psychological distress (intrusive thoughts, anger, feelings of helplessness, anxiety, stress and depression) than victims of non-bias crimes (Herek et al., 2002). The Leicester Hate Crime Project outlines the mental and physical impact of hate crime victims, with $51 \%$ feeling depressed, $46 \%$ feeling suicidal and $41 \%$ turning to alcohol (Chakraborti et al., 2014). A recent study examines the emotional and behavioural responses to hate crime, highlighting the role of anger for some respondents and for others taking action against perceived injustice (Walters et al., 2020). The most recent Crime Survey for England and Wales on Hate Crime (Home Office, 2020) reiterated the extent of the impact, by describing that victims of hate crime are more than twice as likely to experience fear, difficulty sleeping, anxiety, panic attacks, depression or crying, compared with overall victims of CSEW crime.

On a wider scale, hate crimes have major implications for communities, not merely targeted individuals (Craig, 2002; Dzelme, 2008). Hate crimes were defined by Levin and McDevitt (1993) as 'message crimes'. They aim not only to subordinate the victim, but to send a message to the 
community that the perpetrator finds the group's identity offensive and that it needs to be met with violence or intimidation. 'Any single incident has threatening implications for all members of that group and reminds them that they could be next' (Craig, 2002: 119). In this respect, hate crimes are considered to be a crime like no other.

It is against this backdrop of a resurgence of antisemitism, the increased risk of victimisation, and the impact that it has both on individuals as well as on communities, that conducting research among exclusively the Orthodox Jewish community was of tangible significance.

\section{The Orthodox Jewish community}

A large body of religious laws, customs and tradition govern the standards of behaviour for every aspect of life, including education, work, food and relationships. Orthodox Jews (also known as charedi Jews) prioritise living in cohesive communities in order to have access to religious and cultural facilities. The community provides its members with a rich web of social support (Valins, 2003). There are dozens of charitable organisations (Gemachs) that lend out whatever is required (interest-free money, beds, cots, chairs, bridal wear, postal service, even mother's milk for a mother who is not able to nurse). They have established a cohesive unit dedicated to caring for all of its members. They are required by Jewish law to give a portion of their income to tzedokah (charity money). The men are required to pray three times a day and the week culminates in the Shabbos (which commences at sunset on Fridays). They observe Jewish holidays, buy kosher food only, and attend religious schools. Social identity theory, which proposes that individuals form attachments and a sense of belonging to groups with which they share similar identity-defining characteristics (Tajfel and Turner, 1986), would help explain the nature of this community as a close-knit, self-contained community whose religious observance provides the community's structure and way of life. They represent a thriving community, based on strong religious values and close community ties, within the multi-cultural, multi-faith London of the 21 st century.

The charedi communities in London live within tight geographical borders. The research explored antisemitism within the two charedi communities of London - Stamford Hill and North West London. These are the two most concentrated neighbourhoods where charedi Jews reside in London. Whilst there may be geographical and ideological differences between these two neighbourhoods, these Jewish residents are both considered charedi.

'Nationally, Jews comprise just $0.5 \%$ of the national population, but at the local level that proportion rises to as much as 40\% in some places' (Graham, 2011: 2). Greater London accounts for $65.3 \%$ of the total Jewish population in Britain (2011 Census results: Office for National Statistics, 2016). The strictly Orthodox Jewish population constitute a minority of the total Jewish population in the UK. Of the 271,259 Jews living within the UK, 43,571 are strictly Orthodox Jews, forming $16 \%$ of the overall Jewish population (Office for National Statistics, 2016). The 2011 census, which is now dated, revealed that the borough with the largest Jewish population is Barnet (North West London) accounting for 14,024 Jews, whilst Hackney (Stamford Hill) accounted for 8,209 Jews.

\section{Research on coping mechanisms}

Extensive research has been carried out in relation to hate crime victimisation and the coping mechanisms which hate crime victims adopted in managing the victimisation (Breakwell, 1986; Faulkner and Hecht, 2011; Leets, 2002; Perry, 2014). The literature on victims of hate crime 
indicates that there are four strategies in responding to hate crime victimisation. The first three are more common; namely withdrawal, isolation or limiting the expression of individual identity. The fourth response, which is far less prevalent, is accepting the victimisation and continuing to function, with very little change. It ought to be noted at this stage that the strategies adopted relate not only to direct victims but often to the vicarious victims as well, who feel the need to make certain behavioural changes (Paterson et al., 2018).

Coping mechanisms are the preventative steps which are taken by individuals to avoid future victimisation. In order to lessen vulnerability to crime and because of fear of re-victimisation, victims of hate crime often adopt certain coping mechanisms. 'Coping with victimisation is ... a process that involves rebuilding one's assumptive world (that the world is a safe place)' (JanoffBulman and Frieze, 1983: 1-2). Research indicates that once victimised, 'there appears to be an increased perceived vulnerability to crime' (Winkel, 1998 cited in Shapland and Hall, 2007: 179). The quantitative research of Tseloni (2007) shows that past victimisation 'nearly doubles the odds ratio of fear of crime' (Tseloni, 2007: 3). There is also research on fear of crime which reflects that there are instances whereby individuals fear crime even though they had not been victims of crime (Prieto and Bishop, 2016). This disparity between high levels of fear and downward trends in crime has been well researched, with fear of crime historically being out of proportion to levels of crime (Hough, 2017). It is on this basis that victims adopt precautionary measures to manage future victimisation.

The coping mechanisms which Orthodox Jews adopt in managing antisemitism have been largely absent from academic debate and analysis. My study added to the limited literature in that my research explored coping mechanisms within the Orthodox Jewish community exclusively. The findings revealed that the way the Orthodox Jewish community have managed their victimisation through antisemitism has been profoundly different from the dominant narratives of victims of hate crime.

\section{Withdrawal}

The first coping mechanism which individuals adopt in order to limit the risk of further victimisation has been researched by Dzelme (2008). The various strategies which victims adopt include attempts to construct personal safety measures, limit social activities, withdrawal and emigration. Victims may modify their daily activities, purchase security devices and increase safety precautions for dependants. Victims create 'personal safety nets'; reduce their social circles, view most relationships with wariness and build a small social network consisting of trustworthy friends and family members (Dzelme, 2008). Boeckmann and Turpin-Petrosino (2002) discuss minorities of specific sexual orientation limiting their opportunities to socialise and expressing themselves to those who would be sympathetic to their choices. These individuals feel more comfortable in being part of non-critical, accepting, safe circles. By limiting social circles, they attempt to limit victimisation and hence reduce negativity in their lives.

\section{Isolation}

The second coping mechanism is isolation. Whilst isolation is interlinked with withdrawal, victims not only withdraw from certain circles; they make a choice to remove themselves all together. Victims isolate themselves in order to stand out as distinct, to reduce the possibility of being rejected and to minimise the possibility of having their self-esteem dented (Breakwell, 1986). 
Others voice feelings of solitude and general caution in other relationship contexts (Breakwell, 1986). Some take it even a step further by not only attempting to be less visible, but also resorting to moving neighbourhoods (Weiss et al., 1991-92).

\section{Limiting expression of individual identity}

Research has shown that the third coping mechanism that some individuals adopt is limiting the expression of individual identity by taking steps to become less visibly identifiable. There is extensive research on anti-Muslim victimisation, revealing that many have chosen to become less identifiable. Many Muslim women fearing victimisation have questioned their choice to be covered by the hijab and having been forced to give priority to their own safety over the expression of their religious identity (Awan and Zempi, 2015; Zempi and Chakraborti, 2014). 'Veiled Muslim women often try to become less "visible" and as such less vulnerable by removing the veil' (Zempi, 2014: 156). Similarly, some adopt western names in order to conceal their Muslim identity or by dressing in western clothes (Awan and Zempi, 2015). Perry and Alvi (2012: 20) emphasise that this is not a voluntary choice, but the 'safe' choice. Taking heed of their personal safety has become of utmost importance (Perry, 2014).

Given the increasing number of antisemitic incidents, one would also expect to see fewer numbers of Jews openly displaying their Jewish identity in public. Paradoxically, Staetsky and Boyd (2014) highlight that in recent decades there is evidence of a greater number of Jews asserting themselves visually by continuing to wear kippot (skullcaps) and major Jewish events continuing to be publicly displayed. They assert that antisemitism 'remains rather a conundrum' (Staetsky and Boyd, 2014: 8) as individuals are not shying away from displaying their Jewish identity, despite a rise in incidents. This survey suggests that the rise in antisemitism is not affecting their religious expression. Social identity theory is applicable in reinforcing the importance that they place on enhancing and strengthening their group identity, despite adversity.

\section{Acceptance/normalisation}

The fourth coping mechanism has previously been termed by Sweiry (2014) as normalisation; namely, that the respondents accepted the victimisation. This reverse response to victimisation, which is less prevalent, is what Robert Merton (1938) would describe as acceptance. A study conducted by Hein and Scharer (2013) compares LGBT victims with victims of religious, ethnic or race hate crimes. They assert that in this latter group the victims have been raised to deal with their individual beliefs. Hein and Scharer (2013) claim that these coping skills have either been directly taught or role modelled by an adult within the community. There is an implied understanding, they state, that the community will assist and support a targeted individual. In a recent article, Hardy and Chakraborti (2020) commented that 'within this smaller sample of participants', where victimisation formed part of their day-to-day life, this victimisation was 'normalised'. Interviewees recounted developing 'thick skin and had accepted that they will encounter hostility as a result of being different' (Hardy and Chakraborty, 2020: 119).

Delving further as to whether Jewish individuals are in some way more resilient to hate crime, Sweiry (2014) describes a range of coping mechanisms which were adopted to manage the hurt and to prevent future victimisation. A few respondents chose normalisation, but the vast majority of his respondents had adopted preventative coping mechanisms. Some chose to negotiate their identity, by removing their kippot. Others felt the need to control space out of fear of antisemitism and 
avoided certain public places. Others took preventative measures such as choosing where to live or which school to send their children to. One went as far as choosing to emigrate and another was in the process of emigrating. This shows that more acute preventative mechanisms were adopted by secular Jews who were more assimilated into society. The Orthodox Jews in Sweiry's sample articulated that due to the high frequency of victimisation, they have accepted the victimisation as a normal part of their lives. While Sweiry's research is unique in its kind, the obvious limitation of his study is that the data were collected at a time unlike the current climate. The current climate of my research was at a period of time during which there was much discourse about antisemitism. My research aims to investigate coping mechanisms within the Orthodox Jewish community exclusively to either support or extend these ideas. My research is distinctive as the research took place in two highly important locales in North London, the sample was exclusively Orthodox Jewish and finally the research was conducted at a time at which there was a resurgence of antisemitism.

\section{Methodology}

This research is an interpretative qualitative piece of writing. A qualitative approach was adopted in order to gain a deeper understanding of participants' experiences. Morrow (2007) notes that qualitative techniques are the 'most useful approach to understanding the meanings people make of their experiences' and 'delve into complex processes and illustrate the multifaceted nature of human phenomena'. Adopting qualitative research methods gives depth as to the personal and social meanings of the victimisation and the way victims manage their responses to the victimisation. Conducting quantitative research, particularly in circumstances such as this research, where the sample is a 'hard-to-reach' group, would not give due insight to the complex issues behind the victimisation. Quantitative methods provide a snapshot of perceptions and actions, whereas victimisation is a process. As such, a qualitative approach best served to explore this process.

This qualitative study is based on a sample of 28 in-depth interviews and five focus groups. In order to ensure transparency and rigour, these research methods were combined (Lambert and Loiselle, 2008). Combining these two research methods contributed to the exploration of individual accounts (interviews) within contextual circumstances surrounding the phenomenon (focus groups). Hence, the focus groups were used to complement the interviews so as to gather richer data and expand the scope of the study. To access individual participants, an advertisement was placed on the largest online Jewish website, which reaches out to several thousand Jews, who are predominantly based in Barnet. Several responses were received to that advertisement, resulting in a handful of interviews. The second group of interviewees were accrued using snowball sampling. In obtaining access to respondents from Stamford Hill, I approached a 'gatekeeper', who made the introduction between the respondents and me. The impact of knowing this gatekeeper was the ability to eventually access a broad spectrum of individuals.

Participants' ages ranged from 18 to 75 with half of the respondents being male and the other half female, from varying marital and different professional statuses. Of the 28 participants, 6 participants were subjected to physical violence or assault; one of which resulted in lifethreatening injuries. Verbal abuse was a particularly common feature for these participants with 16 interviewees reporting having been subjected to verbal abuse at least once. Most of those who were subjected to verbal abuse described a catalogue of incidents dating back to when they were children. Six participants related incidents of discrimination on a university campus or in employment. Participants were also subjected to seven other incidents within other categories. 
Focus groups were conducted with a range of local key stakeholders, voluntary neighbourhoodwatch organisations and the police. The collection of the data was research specific as it took place in two highly important localities in North London; these being the two most concentrated neighbourhoods where Orthodox Jews reside. The research was inspired by three interlinked theoretical strands: symbolic interactionism (Mead, 1934), identity theory (Stryker, 1968, 1980) and social identity theory (Tajfel and Turner, 1986). Interviews were coded using NVivo and thematic analysis was used to analyse the data (Braun and Clarke, 2006).

Even though I came into this research as someone who has never experienced antisemitism personally, I was an insider to the respondents. Being an insider has allowed me to gain access to this hard-to-reach group. It also benefited the research process as there was a greater understanding of the culture and an established intimacy which maintained the flow of interaction. This in turn, eased our transition into the more sensitive and enabled rich data collection.

\section{Findings}

The main coping mechanism which respondents adopted in my research was one of normalisation. Despite the frequency of victimisation and despite an awareness that there is a resurgence of antisemitism, by and large, the vast majority of participants who were victimised had accepted the victimisation. Respondents, on the whole, did not choose withdrawal or isolation, and were in fact unmovable in negotiating their religious identity. Approximately three-quarters of the victimised respondents expressed a high level of acceptance for the victimisation. I will propose that the respondents had managed to respond in this way due to two distinct yet overlapping factors - their strong religious upbringing and their close community ties. The victimisation did not have the effect of them questioning their faith, but rather in a strengthening of their beliefs and the establishment of closer ties with their community.

In contrast to the vast majority of participants who routinely ignored, minimised or dismissed the victimisation, a minority (a quarter) of respondents adopted preventative measures to avoid future victimisation. Correspondingly, these preventative measures, similar to the dominant narratives of other victims of hate crime, included adopting strategies such as heightening security measures, taking avoidance measures and consideration given to identity negotiation, to emigration and applying for foreign passports. However, the instances whereby respondents adopted preventative measures were a smaller proportion, and this article focuses on the large proportion of respondents.

\section{Understanding normalisation}

The apparent ability of respondents to show higher levels of tolerance towards victimisation was palpable. When respondents were asked about the impact that the antisemitic attack had on them, many of those victimised dismissed the victimisation as 'not a big deal' or 'as part of being Jewish'. When asked what their immediate response was to the incident, most participants responded that ongoing abuse was normal and very much part of life, seeming to have little effect.

Just as participants had managed to accept the victimisation in the aftermath of the incident, the data reflect that this feeling of acceptance extended itself in the long term, in not adopting mainstream coping mechanisms. One respondent commented: 'I experience so much abuse on a regular basis that it has become part of my life. I just accept it'. Another said: 
people just accept it ... I'm talking about the car that passes shouting out of the car: Heil Hitler. That kind of thing. That's just part of it. They accept it and move on. They see it as part of life.

Another stressed that:

At the end of the day, I need to get on with my life. Part of me thinks, why should I allow them to control my life and dictate how I live. I got attacked on the street. OK, it can happen to anybody. It happens all the time, people get robbed, people get mugged. People get attacked. It happens. Stuff happens to you in life.

These data are consistent with research conducted with homosexual victims who have normalised the incidents and who 'often minimise the impact of hate motivated verbal attacks' (Garnets et al., 1992: 215). It is also in line with the work of Githens-Mazer and Lambert (2010) which showed that accepting the victimisation was a mindful coping mechanism. By accepting or normalising the incidents, participants did not choose to isolate themselves, or withdraw themselves, nor to shape their identity. Nor did they take matters further; there was acceptance and they did not wallow in it. From a young age, it is common for Jewish (Israeli) youths to experience some form of antagonism and to become skilled in processing it (Dor-Shav, 1990). 'Jews, as a group, are better equipped than homosexuals, to deal with prejudice and discrimination' (Leets, 2002: 346).

This normalisation of these incidents was evident in four ways throughout the research. First, the research has culminated in many participants overlooking the incident in the aftermath of the victimisation. Second, normalising was observable in discounting the idea of reporting the abuse. In only four of the incidents did participants choose to report to the police. Their choosing not to report it further supports the notion that they accepted the victimisation as part of their day-to-day life. Third, normalisation was evident in not adopting other coping mechanisms to deter future victimisation, such as withdrawal, isolation or identity negotiation. A further noticeable sign of normalisation was that the victimisation was rarely discussed with others. Whilst in the immediate aftermath, the victim would share the incident with another, it would not be laboured with others. The fact that many victims rarely discussed the incidents with others is reflective of the fact that it was not such a pressing issue and that participants normalised the incidents.

The question which arises is whether by choosing not to take matters further, it is a genuine dismissal of the incident or whether it is a forceful attempt not to be labelled as a victim. According to Mythen et al. (2009), by ignoring the abuse or dismissing it as 'not serious', victims chose not to view themselves or to be defined by others as victims. This research suggests that choosing to accept the victimisation was a form of agency. It is a coping mechanism, a choice, intended so as not to allow the abuse to escalate. Deciding to ignore the abuse was a form of resistance in itself.

Hence, a distinctive pattern of normalising these experiences proved to be the main coping mechanism adopted by those who had experienced antisemitism. Dismissing these incidents as inevitable allowed Orthodox Jews to function as British Jews. The pattern of normalising the hurt was used to rationalise its existence, to justify that some level of hostility is inevitable. I propose that respondents had managed to respond in this way, due to two distinct yet overlapping factors - their strong religious identity and their close community ties. I will turn to discuss each in turn. 


\section{Religious coping}

As a prelude to the discussion, it needs to be stressed that religion is a fundamental tenet of an Orthodox Jewish life. As all the participants are exclusively Orthodox Jews and therefore monotheists, these experiences cannot be seen in isolation to G-d. In accordance with the theoretical framework of identity theory, their level of salience to their religious identity is very high. Their belief in G-d is enmeshed into their being and therefore, when faced with any incident, individuals will question its meaning and significance. As Donin (1972: 30) claimed, the Jewish religion 'is a source of cultural and personal identity ... and provides values to guide throughout all life'.

The large majority of participants emphasised their strong Jewish identity: 'I feel sturdy and solid in my Jewishness', 'It's overriding strong', 'I grew up with it. Without it I guess I'd be a bit lost'. 'Very much an essential part of my life'. 'It defines me. Apart from being female, being Jewish is the next thing', 'It's my life. It's who I am. It's very integral. It's part of me', 'When I meet people, new people, I always first tell them that I am a Jew', 'Being Jewish is an integral part of your identity', 'Totally, totally. It's the top thing. Everything floats from there'. One respondents recalled what she termed as her 'glass speech':

There was somebody who spoke about time management and they introduced the topic by producing a glass. And he said I could put various things in the glass. What should I put in the glass first? He filled the glass with the biggest stones first. Is the glass full? Then he took gravel. Is it full now? Then he took sand? Is it full now? Then he took water and filled it to the top. You can achieve much more in your life according to what you put in the glass. And when I give speeches, I've always said that the big stones are Judaism. Everything is around that. I've always said, that I couldn't be a mother, I couldn't do the things that I do, and especially I couldn't fit in my working life, if I didn't put those stones first.

Religion is often at the core of individual and group identity. Mol (1976) labelled the primary role of religion as the equilibrium of the individual and group identity. According to Mol (1976: 3), religion resists constant change and by doing so, affords individuals more 'secure anchors for selfreference'. Mol (1976) claims that religion provides the predictability and permanency that individuals need in order to sustain a sense of psychological stability. Phinney (1990: 499) illuminates that ethnic identity is critically important to the individual's psychological well-being when the ethnic group is 'at best poorly represented (politically, economically, and in the media) and ... at worst discriminated against or even attacked verbally and physically'.

But religion goes a step further than enhancing individual and group identity. Earlier studies report that religion acts as a medium for individuals to cope with stressful situations (Park, 2005). Ai and Park (2005) argued that not everyone who has experienced trauma ends up developing mental and physical issues, and that being religious dampens the trauma. Research has shown that when traumatic life events take place, many people would turn to their religion. By way of example, a community-based survey has shown that the second most commonly used strategy after the September 11 terrorist attacks was to turn to religion (Schuster et al., 2001). So, too, religion was used as the most common coping strategy in a study of Pakistani earthquake survivors (Feder et al., 2013) and in 37\% of older adult respondents who had been displaced by Hurricane Katrina (Henderson et al., 2010). Religious coping was also evident in cases of severe disease (Koenig et al., 2001).

Hate crime studies have also revealed that religion can act as an imperative coping mechanism for victims (Shorter-Gooden, 2004; Spalek, 2002). Spalek's research (2002) concerned the victimisation 
experiences of Muslim women. It illuminated that meditation and prayer were common responses to crime, with one participant going to the local Imam to ask for special prayers for protection.

The data herein were consistent with the above studies. Participants were cognisant that part of the way that they obtained their sense of security or resilience was through the bond of their religion. If anything, the victimisation did not result in them questioning their faith but rather in a strengthening of their beliefs. For some, being subjected to antisemitism had led to the reinforcement of a Jewish identity. One respondent commented: 'I do feel that antisemitism changes who I am as a Jew. Otherwise we would have assimilated hundreds of years ago. It makes me stronger as a Jew'. Another interview respondent stated: 'What happened to me (referring to his victimisation) ... has made me closer to Hashem (G-d)'. Another interview respondent who faced a near death experience, described deep appreciation to G-d for sparing his life, he described that it enhanced his belief in G-d, and that a true miracle had happened:

It's an experience which has given me a lot of chizzuk (belief in G-d). We make a point of making a seuda hodaah (a meal of thanks) every year, on that anniversary (of the attack). And it's an experience to grow from. To realise that a nes (a miracle) happened, that it's to be appreciated. Every day of life is a gift.

This respondent, who faced a near death experience, not only expressed deep appreciation for being spared his life, he recounted that a second miracle unfolded, which was that he not only recovered physically, he had also left the incident emotionally unscarred. He described:

It was a nes (a miracle) that I was not suffering from nightmares or dreams or whatever. Or just being OK with leaving the house. Very initially I did have a bit of an issue, that sort of thing, looking over my shoulder. But the Rabbi, I discussed it with him and he put my mind to rest. Saying to me that no one is trying to get me. I would not have coped with it in the same way if I wasn't living a Torah based lifestyle.

Another stated that these incidents ultimately 'strengthen one's Emunah (belief in G-d)'. An additional respondent, who was assaulted on the train from Newcastle, said:

It doesn't shake my faith. It has made me closer to Hashem ... (G-d). These things happen for a reason, and when it happens, you need to ask yourself what is your relationship to Hashem. When this was all happening, I was duvening, I was saying Tehilim (psalms), and it worked.

This is consistent with Zempi's research on veiled Muslim women, who found that experiences of Islamophobic victimisation have awoken hidden Muslim identities (Zempi, 2014).

In accordance with symbolic interactionism, which posits that individuals behave towards things or others (objects) based on the meaning they attach to those things or people and that these interpretations are derived from social interactions (Goffman, 1959; Mead, 1934), the meaning that participants gave these incidents equipped them to curtail the harm by assessing and rationalising their victimisation experiences. A religious belief system helps to interpret life events and gives them meaning and coherence. Koenig (2006) claims that a religious belief system contributes to the psychological integration of traumatic experiences.

In this section several studies have shown that many people cope with traumatic or stressor events based on their religious beliefs, this being consistent with my data. Participants were able to 
normalise the victimisation because of their strong religious identity. Participants held on to a conviction that their lives have meaning, and a belief that things will work out in the end, despite unfavourable odds. Ultimately, what is ostensible from the data is that these victims are not passive sufferers of victimisation, but that the nature and strength of their religious identity has the effect of curtailing the trauma.

\section{Close community ties}

This article proposes that the second reason participants were able to normalise the victimisation is their close community ties or social cohesion. The Orthodox Jewish community provides rich webs of family and social support for its members. Living in close proximity to other Jews, working, socialising and attending local synagogues, all these interactions further strengthen the group identity.

Through the lenses of social identity theory, our interpersonal relationships, particularly in the context of the groups in which we participate, are central to the project of achieving a secure and positive sense of self. Individuals seek a secure sense of self by 'striving to achieve or maintain positive social identity' (Tajfel and Turner, 1986: 16). Threats to the in-group are experienced as threats to individual identity (Bloom, 1990) and vice versa. The individual and the group are interlinked. When faced with adversity, members of the group will respond to its inadequate social identity in one of several ways. According to Tajfel and Turner (1986) some may put efforts into assimilating themselves into the out-group, others will put efforts into enhancing and strengthening the group identity. On an emotional level, studies show that the victims who have a strong identification with their community are more assertive in their response, seeking help and support, whereas those who lack strong identification with the group are prone to psychological issues (Boeckmann and Turpin-Petrosino, 2002).

Intergroup emotions theory (Mackie et al., 2000) is a connected theory which posits that individuals who belong to a particular in-group will interpret events in terms of the implications they have for the in-group, rather than the individual personally. A recent study found that Muslim people are likely to share an affinity with other Muslims: that they experience 'a strong moral bond that was based on a shared cultural and religious belief system' (Walters et al., 2020: 158). There is a myriad of factors which enhance their sense of group identification; their shared values and moral beliefs, and their local access to communal institutions as well as social spaces.

Within the data, the participants also responded by enhancing and strengthening the group identity. The data reveal that the rise in antisemitism only served to bring the community closer. One participant illustrated that 'it (antisemitism) pushes me towards the Jewish community'. Another commented that 'our strength is in our numbers living together'. A certain participant illustrated that Jews have always chosen to live in confined neighbourhoods and remain united in close proximity because of the years of persecution.

A certain respondent, in not referring exclusively to hate incidents, commented that within the Jewish community, 'there will always be someone to help you, you are never alone'. One focus group participant remarked: 'It (antisemitism) is distancing us from the general public. Also there are selected universities where you know that there would be a bigger ensemble of Jews'. Another focus group participant said: 
I think, that to a degree, there is an undercurrent. It may not be verbalised, but that we are all in it together. And if the ship goes down, G-d forbid, if there is a real fear and danger, like the French are starting to feel, then I think we would come together.

These data are consistent with both the work of Leets (2002) who found that Jewish communities have managed to endure centuries of persecution through their persistence, resilience and resilient community structures, and the work of Cohen (2004) who found that the internal cohesion of Jewish communities and group loyalty has been inspired in reaction to the external pressure of antisemitism.

Perhaps it can be argued that the community has adopted an institutionalised coping mechanism. By being self-contained, by setting up infrastructures whereby any aspect of life can be accessed within the neighbourhood - that could be argued to be in response to outside adversarial circumstances. Being able to access employment, education, food, synagogues, all within their respective neighbourhoods, may be said to be a coping mechanism to defend against the rise in antisemitism. The reality is that Orthodox Jewish communities have lived as close-knit communities for centuries and throughout centuries of persecution. It may be that the Orthodox Jewish community prioritise living as part of a cohesive community in order to have ease of access to religious facilities or unconsciously it may be a coping mechanism to protect them from outside prejudices.

Regardless of what the prime motive is behind setting up a close-knit neighbourhood, it is apparent that it is the knowledge that they are part of a whole, which provides participants with a sense of security. It is the bond within the community which gives them the protective measure to be able to accept the victimisation. This article argues that it is the level of strong group identity and the sense of belonging to the community which allows them to normalise these incidents.

\section{Transforming the present}

In summary, Orthodox Jewish respondents have mainly shown higher levels of tolerance towards victimisation, by relying on their religious beliefs and strong community ties, rather than choosing withdrawal or isolation. The study found that the main coping mechanism which participants have adopted was to normalise the incidents. Their experiences of antisemitism have not affected their life in any significant way. This article revealed that the large majority of respondents have not withdrawn, nor strictly avoided certain places, nor negotiated their appearance. The process of victimisation continues with victims adopting certain coping mechanisms which subsequently shape their life. I propose that this act of normalisation is a form of resistance, not to allow the abuse to escalate by having to take further actions. By choosing to normalise their victimisation, they are choosing not to let the victimisation linger. Respondents retained their strong religious identity amidst these potential challenges and they have shown resilience in the face of adversity. Their strong religious identity and close community ties allow them to hold on to the conviction that their lives have meaning, that there is a sense of belonging. Their strong Jewish identity and social cohesion gives them the security and strength not to stagnate.

The choice to normalise the antisemitic incidents ought not to deflect the need for change. This community has been pushed into a situation where they have managed to normalise their victimisation and they are managing on a day-to-day basis. But this should not avert the need for a collective appraisal of developing more effective responses to dealing with the higher rate of victimisation among the Orthodox Jewish community. Antisemitism is a stain in our society. It 
is a complex phenomenon that has spanned generations. The Orthodox Jewish community is the most visible and at highest risk of victimisation. They are also the section of the Jewish population that is growing at a rapid rate. The increase in the rate of incidents must not be allowed to continue. The prevalence of antisemitic incidents among the Orthodox Jewish community calls for the development of an effective and comprehensive response to antisemitism among this marginalised group.

\section{References}

Ai AL and Park CL (2005) Possibilities of the positive following violence and trauma: informing the coming decade of research, Journal of Interpersonal Violence 20(2): 242-250.

Awan I and Zempi I (2015) We fear for our lives: offline and online experiences of anti-Muslim hostility. Available at: http://irep.ntu.ac.uk/id/eprint/25975/1/221908_3389.pdf (accessed 19 August 2018).

Bloom W (1990) Personal Identity, National Identity and International Relationships. Cambridge: Cambridge University Press.

Boeckmann R and Turpin-Petrosino C (2002) Understanding the harm of hate crime. Journal of Social Issues 58(2): 207-225.

Braun V and Clarke V (2006) Using thematic analysis in psychology. Qualitative Research in Psychology 3(2): 77-101.

Breakwell GM (1986) Coping with Threatened Identity. London: Methuen.

Chakraborti N, Garland J and Hardy SJ (2014) The Leicester hate crime project: findings and conclusions. University of Leicester, UK.

Cohen EH (2004) Components and symbols of ethnic identity: case study in informal education and identity formation in Diaspora. Applied Psychology: An International Review 53(1): 87-112.

Community Security Trust (CST) (2017) Antisemitic Incidents Report 2016. Available at: https://cst.org.uk/ data/file/b/e/Incidents\%20Report\%202016.1486376547.pdf (accessed 21 February 2017).

Corcoran H and Smith K (2016) Hate crime, England and Wales, 2015/16. Home Office Statistical Bulletin 11/16. Available at: https://www.gov.uk/government/uploads/system/uploads/attachment_data/file/5593 19/hate-crime-1516-hosb1116.pdf (accessed 14 November 2016).

Craig KM (2002) Examining hate motivated aggression: a review of the social psychological literature on hate crimes as a distinct form of aggression. In: Perry B. (ed.) Hate and Bias Crime: A Reader. London: Routledge, 117-130.

Donin H (1972) To be a Jew: A Guide to Jewish Observance in Contemporary Life. New York: Basic Books.

Dor-Shav Z (1990) Development of an ethnic self-definition: the ethnic self-concept "Jew" among Israeli children. International Journal of Behavioural Development 13(3): 317-332.

Dzelme I (2008) Psychological effects of hate crime. Available at: http://cilvektiesibas.org.lv/site/attach ments/30/01/2012/Naida_noziegums_ENG_cietusajiem_Internetam.pdf (accessed 23 March 2017).

Faulkner SL and Hecht ML (2011) The negotiation of closetable identities: a narrative analysis of LGBTQ Jewish identity. Journal of Social and Personal Relationships 28(6): 829-847.

Feder A, Ahmed S and Lee E. (2013) Coping and PTSD symptoms in Pakistani earthquake survivors: purpose in life, religious coping and social support. Journal of Affective Disorders 147: 156-163.

FRA (2013) Discrimination and hate crime against Jews in EU Member States: experiences and perceptions of antisemitism. Available at: https://fra.europa.eu/en/publication/2013/discrimination-and-hate-crimeagainst-jews-eu-member-states-experiences-and (accessed 27 June 2018).

Garnets L, Herek G and Levy B (1992) Violence and victimization of lesbians and gay men: mental health consequences. In: Herek G and Berrill K (eds) Hate Crimes: Confronting Violence against Lesbians and Gay Men. Newbury Park: Sage, 207-226. 
Githens-Mazer J and Lambert R (2010) Islamophobia and Anti-Muslim Hate Crime: A London Case Study. European Muslim Research Centre (EMRC). Available at: https://www.counterextremism.org/resources/ details/id/107/islamophobia-and-anti-muslim-hate-crime-a-london-case-study (accessed 22 March 2017).

Goffman E (1959) The Presentation of Self in Everyday Life. London: Penguin Books.

Graham D (2011) Census results (England and Wales) initial insights into Jewish neighbourhoods. Institute for Jewish Policy Research, London.

Hardy SJ and Chakraborti N (2020) Blood, Threats and Fears. ProQuest Ebook Central: Palgrave Hate Studies.

Hastings C (2005) Chief Rabbi warns of anti-Semitic tsunami. The Telegraph, 1 January. Available at https:// www.telegraph.co.uk/news/uknews/1506746/Chief-Rabbi-warns-of-anti-Semitic-tsunami.html (accessed 26 January 2018).

Hein L and Scharer M (2013) Who cares if it is a hate crime? Lesbian, gay, bisexual, and transgender hate crimes: mental health implications and interventions. Perspectives in Psychiatric Care 49(2): 84-93.

Henderson TL, Roberto KA and Kam Y (2010) Older adult responses to hurricane Katrina: daily hassles and coping strategies. Journal of Applied Gerontology 29: 48-69.

Herek G, Cogan J and Gillis R (2002) Victim experiences in hate crimes based on sexual orientation. Journal of Social Issues 58(2): 319-340.

Home Affairs Committee (2016) Antisemitism in the UK. HC 136. Available at: http://www.publications. parliament.uk/pa/cm201617/cmselect/cmhaff/136/136.pdf (accessed 1 November 2016).

Home Office (2020) Hate crime, England and Wales, 2019/20. Statistical Bulletin 29/20. Available at: https:// www.gov.uk/government/publications/hate-crime-england-and-wales-2019-to-2020/hate-crime-englandand-wales-2019-to-2020\#fnref:8 (accessed 29 December 2020).

Hough M (2017) The discovery of fear of crime in the UK. In: Murry L and Mythen G (eds) The Routledge International Handbook on Fear of Crime. London: Routledge, 35-46. Available at: https://www.routle dgehandbooks.com/doi/10.4324/9781315651781-4 (accessed 26 Dec 2020).

Iganski P and Lagou S (2014) The personal injuries of hate crime. In: Hall N, Corb A and Giannasi P (eds) The Routledge International Handbook on Hate Crime. London: Routledge, 34-46.

Janoff-Bulman R and Frieze I (1983) A theoretical perspective for understanding reactions to victimisation. Journal of Social Issues 39(2): 1-17.

Koenig HG (2006) In the Wake of Disaster: Religious Responses to Terrorism and Catastrophe. Philadelphia: Templeton Foundation Press.

Koenig HG, Larson DB and Larson SS (2001) Religion and coping with serious medical illness. Annals of Pharmacotherapy 35(3): 352-359.

Kushner T (2013) Anti-Semitism in Britain: continuity and the absence of a resurgence? Ethnic and Racial Studies 36(3): 434-449.

Lambert SD and Loiselle CG (2008) Combining individual interviews and focus groups to enhance data richness. Journal of Advanced Nursing 62: 228-237.

Leets L (2002) Experiencing hate speech: perceptions and responses to antisemitism and antigay speech. Journal of Social Issues 58(2): 341-361.

Levin J and McDevitt J (1993) Hate Crimes: The Rising Tide of Bigotry and Bloodshed. New York: Plenum Press.

Mackie DM, Devos T and Smith ER (2000) Intergroup emotions: Explaining offensive action tendencies in an intergroup context. Journal of Personality and Social Psychology 79: 602-616.

Mead GH (1934) Mind, Self \& Society: From the Standpoint of a Social Behaviorist. Chicago: University of Chicago Press.

Merton R (1938) Social structure and anomie. American Sociological Review 3(5): 672-682. 
Mol H (1976) Identity and the Sacred: A Sketch for a New Social-Scientific Theory of Religion. Oxford: Basil Blackwell.

Morgan J (2017) Anti-Semitic attacks in the UK reach record high. Evening Standard, 27 July. Available at: https://www.standard.co.uk/news/london/antisemitic-attacks-in-uk-reach-record-high-a3597316.html (accessed 18 June 2018).

Morrow SL (2007) Qualitative research in counseling psychology: Conceptual foundations. The Counseling Psychologist 35(2): 209-235.

Mythen G, Walklate S and Khan F (2009) 'I'm a Muslim, but I'm not a terrorist': victimisation, risky identities and the performance of safety. British Journal of Criminology 49(6): 736-754.

Office for National Statistics, National Records of Scotland, Northern Ireland Statistics and Research Agency (2016) 2011 Census aggregate data. UK Data Service (June 2016). Available at: http://dx.doi.org/10.5257/ census/aggregate-2011-1 (accessed 22 March 2017).

Park CL (2005) Religion as a meaning-making framework in coping with life stress. Journal of Social Issues 61(4): 707-729.

Paterson JL, Walters MA, Brown R, et al. (2018) The Sussex Hate Crime Project: Final Report. University of Sussex. Available at: https:/www.sussex.ac.uk/webteam/gateway/file.php?name=sussex-hatecrime-project-report.pdf\&site $=430$ (accessed 28 March 2018).

Perry B (2014) Gendered Islamophobia: hate crime against Muslim women, Social Identities 20(1): 74-89.

Perry B and Alvi S (2012) 'We are all vulnerable': The in terrorem effects of hate crimes. International Review of Victimology 18(1): 57-71.

Phinney JS (1990) Ethnic identity in adolescents and adults: Review of research. Psychological Bulletin 108: 499-514.

Prieto CR and Bishop SR (2016) A measure of the concentration of rare events. Scientific Reports 6: 32369.

Schuster MA, Stein BD, Jaycox LH, et al. (2001) A national survey of stress reactions after the September 11, 2001, terrorist attacks. New England Journal of Medicine 345: 1507-1512.

Shapland J and Hall M (2007) What do we know about the effects of crime on victims? International Review of Victimology 14(2): 175-217.

Shorter-Gooden K (2004). Multiple resistance strategies: How African American women cope with racism and sexism. The Journal of Black Psychology 30(3): 406-425.

Spalek B (2002) Religious diversity, British Muslims, crime and victimisation. In: Spalek B (ed.) Islam, Crime and Criminal Justice. Cullompton: Willan, 1-15.

Staetsky LD and Boyd J (2014) The exceptional case? Perceptions and experiences of antisemitism among Jews in the United Kingdom. JPR Report, Institute for Jewish Policy Research. Available at: http://www. jpr.org.uk/documents/Perceptions_and_experiences_of_antisemitism_among_Jews_in_UK.pdf (accessed 22 March 2017).

Stryker S (1968) Identity salience and role performance. Journal of Marriage and the Family 4(4): 558-564.

Stryker S (1980) Symbolic Interactionism: A Social Structural Version. Menlo Park: Benjamin/Cummings.

Sweiry A (2014) Antisemitism in the lives of British Jews: experiences, fears and responses. Unpublished PhD thesis, Lancaster University, UK.

Tajfel H and Turner JC (1986) The social identity theory of intergroup behaviour. In: Worchel S and Austin WG (eds) Psychology of Intergroup Relationship. Monterey: Brooks Cole, 34-47.

Tseloni A (2007) Fear of crime, perceived disorders and property crime: a multivariate analysis at the area level. Crime Prevention Studies 21: 163-185.

Valins O (2003) Stubborn identities and the construction of socio-spatial boundaries: Ultra-Orthodox Jews living in contemporary Britain. Transactions of the Institute of British Geographers 28(2): 158-175. 
Walters M, Paterson J, McDonnell L, et al. (2020) Group identity, empathy and shared suffering: Understanding the 'community' impacts of anti-LGBT and Islamophobic hate crimes. International Review of Victimology 26(2): 143-162.

Weiss JC, Ehrlich H and Larcom B (1991-92) Ethnoviolence at work. The Journal of Intergroup Relationships 18(4): 28-29.

Zempi I (2014) Unveiling Islamophobia: The Victimisation of Veiled Muslim Women. Basingstoke: Palgrave Macmillan.

Zempi I and Chakraborti N (2014) Islamophobia, Victimisation and the Veil. Basingstoke: Palgrave Macmillan. 